\title{
Analisis Dinamika Molekul Protein Lysozyme Putih Telur Dengan Model Potensial Lennard-Jones Menggunakan Aplikasi Gromacs
}

\author{
Harry Prayoga ${ }^{(1)^{*}}$, Yanti Yulianti ${ }^{(1)}$, dan Agus Riyanto ${ }^{(1)}$ \\ (1) Jurusan Fisika FMIPA Unila, \\ Jl. Soemantri Brodjonegoro 1, Bandar Lampung 35144. \\ E-mail: harryprayoga4@gmail.com
}

Diterima (21 Mei 2018), Direvisi (4 Juni 2018)

\begin{abstract}
The molecular dynamic analysis oflysozyme protein has been done using Gromacs application. Lysozyme protein filled by water in the cubic form with variation of temperature was $300 \mathrm{~K}, 325 \mathrm{~K}$, and 350 $K$ and calculatedpotential energy values used Lennard Jones equation. Structure protein on temperature was $300 \mathrm{~K}$ showed that pressure value was 2,54 barand density value was $997,54 \mathrm{~kg} / \mathrm{m}^{3}$ then protein changed in unfolded state on ARG21-CA and SER81-CAamino acid chain with potential energy was 2992,14 kJ/mol . Structure protein on temperature was $325 \mathrm{~K}$ showed that pressure value was 4,84 barand density value was $974 \mathrm{~kg} / \mathrm{m}^{3}$ then protein changed in unfolded state on ASP101-CA and GLN121-CAamino acid chainwith potential energy was $2994,55 \mathrm{~kJ} / \mathrm{mol}$.Structure protein on temperature was $350 \mathrm{~K}$ showed that pressure value was 0,82 barand density value was $948,747 \mathrm{~kg} / \mathrm{m}^{3}$ then protein changed in unfolded state on ARG21-CA amino acid chain and lost on GLN121-CA amino acid chainwith potential energy was 2994,55 kJ/mol. Root Mean Standard Deviation (RMSD) showed that the protein will be denaturated on temperature $350 \mathrm{~K}$ caused bylost on GLN121-CA amino acid with distance was $0.07 \mathrm{~nm}$.
\end{abstract}

Keywords: molecular dynamics, Lennard-Jones, lysozyme, Gromacs.

Abstrak.Telah dilakukan analisis dinamika molekul protein lysozyme putih telur yang diselimuti air bentuk kubik dengan variasi temperatur $300 \mathrm{~K}, 325 \mathrm{~K}$, dan $350 \mathrm{~K}$ serta melakukan perhitungan nilai energi potensial dengan persamaan Lennard Jones yang dilakukan dengan aplikasi Gromacs.Pada temperatur 300 Kmenunjukan nilai tekanan 2,54 bardan nilai densitas $997,54 \mathrm{~kg} / \mathrm{m}^{3}$ serta terjadi perubahan unfolded state di rantai asam amino ARG21-CA dan SER81-CA yang menghasilkan energi potensial 2992,14 kJ/mol. Pada temperatur $325 \mathrm{~K}$ menunjukan nilai tekanan 4,84 bardan nilai densitas $974 \mathrm{~kg} / \mathrm{m}^{3}$ serta terjadi perubahan unfolded state di rantai asam amino ASP101-CA dan GLN121-CA yang menghasilkan energi potensial $2994,55 \mathrm{~kJ} / \mathrm{mol}$. Pada temperatur $350 \mathrm{~K}$ menunjukan nilai tekanan 0,82 bardan nilai densitas 948,747 $\mathrm{kg} / \mathrm{m}^{3}$ serta terjadi perubahan unfolded state di rantai asam amino ARG21-CA dan menghilangnya rantai asam amino GLN121-CA yang menghasilkan energi potensial 2994,55 kJ/mol. Hasil Root Mean Standart Deviation (RMSD) menunjukan bahwa protein mulai terdenaturasi pada temperatur $350 \mathrm{~K}$ yang ditandai pemutusan rantai asam amino GLN121-CA sejauh $0.07 \mathrm{~nm}$.

Kata kunci:dinamika molekul, Lennard-Jones, lysozyme, Gromacs.

\section{PENDAHULUAN}

Makanan merupakan bahan yang sangat penting untuk kelangsungan hidup manusia karena tubuh manusia membutuhkan energi yang digunakan untuk aktivitas sehari-hari yang memiliki unsur- unsur seperti karbohidrat, protein, mineral, vitamin, dan serat. Protein merupakan polimer dari monomer monomer asam amino yang telah dihubungkan satu sama lain dengan ikatan peptida [1] yang menjadi komponen penting bagi fungsi tubuh manusia yang dapat diperoleh dari protein 
nabati seperti kedelai dan protein hewani seperti telur. Protein putih telur terdiri dari protein serabut yaitu ovomucin dan protein globular yaitu ovalbumin, conalbumin, ovomucoid, lysozyme, flavoprotein, ovoglobulin, ovoinhibitor, dan avidin. Salah satu jenis protein putih telur tersebut yang dapat melawan bakteri adalah lysozyme[2].

Struktur protein terdiri atas struktur primer, sekunder, tersier, dan kuartener [3].Beberapa fungsi protein diantaranya sebagai elemen struktural, sintesis hormon, enzim dan antibodi, serta terlibat dalam transportasi oksigen. Protein dapat melipat secara fungsional dalam bentuk konformasi pada jangka waktu milisekon serta sering kali dapat refold jika ikatan mereka terganggu. Mekanisme untuk menjelaskan stabilitas protein masih menjadi masalah utama yang tidak dipahami sepenuhnya. Banyak faktor yang mempengaruhi stabilitas termal protein. Proses pelipatan dari kebanyakan protein adalah fenomena fisik murni yang tergantung pada urutan asam amino tertentu dari protein dan lingkungan pelarut [3].

Dinamika molekul adalah simulasi komputer yang mengamati pergerakan molekul molekul yang saling berinteraksi dengan menyimulasikan molekul yang saling menarik dan mendorong dan menabrak satu sama lain[4].Teknik ini dapat digunakan dalam mempelajari stabilitas enzim atau protein, struktur protein, perubahan konformasi, pelipatan protein, pengangkutan ion, dll. karena setiap protein memiliki sifat kestabilitas thermal berbeda beda [3].

Salah satu aplikasi yang dapat memvisualisasi struktur molekul dan dapat menyimulasi dinamika molekul salah satunya adalah Gromacs. Gromacs merupakan aplikasi yang melakukan simulasi dinamika molekul berdasarkan pendekatan persamaan hukum newton dan mekanika klasik [1] serta di dasarkan pada mekanika kuantum [5].
Komponen yang paling penting dalam dinamika molekul adalah potensial. Gaya yang sering bekerja pada partikel diturunkan dari potensial ini dan yang sering digunakan adalah energi potensial Lennard-Jones [6]. Oleh karena itu, untuk dapat memecahkan suatu masalah yang sangat rumit maka diperlukan simulasi dengan eksperimen komputer. Eksperimen ini menggunakan metode dinamika molekul dengan protein yang digunakan adalah protein lysozyme putih telur dengan menggunakan potensial Lennard-Jones. Penelitian ini bertujuan untuk mengetahui mengetahui prinsip kerja simulasi dinamika molekul, pengaruh temperatur saat kesetimbangan, serta energi yang terdapat dalam protein lysozyme putih telur. Simulasi dinamika molekul ini dilakukan dengan aplikasi Groningen Machine for Chemical Simulation (Gromacs) yang berjalan di linux yang berdasarkan algoritma Verlet serta visualisasi dilakukan dengan software visualisasiVirtual Molecular Dynamics (VMD).

\section{METODE PENELITIAN}

Penelitian ini dimulai dengan menentukan jenis protein yang digunakan yaitu protein lysozyme yang dapat diunduh dari situs Research Collaboratory for Struktural Bioinformatic (RSCB) dengan kode nama 1AKI.pdb. Protein lysozyme putih telur yang telah didapat mempunyai ukuran 59,062 x 68,451 x 30,517 $\AA$ yang memiliki 1079 atom yang meliputi 613 atom C, 263 atom O, 193 atom $\mathrm{N}$, dan 10 atom S[7] yang terikat oleh ikatan peptida yang terhubung satu sama lain. Selanjutnya disimulasikan dengan menambahkan air pada protein karena protein putih telur mudah larut dalam air dan mudah bereaksi [8] sehingga protein putih telur lysozyme dilarutkan dalam pelarut air. Protein lysozyme putih telur ketika bereaksi dengan air memiliki gaya interaksi antar atom yang 
saling berhubungan sehingga ikatan peptide pada rantai asam amino sangat rentan terputus dengan adanya gangguan yang diberikan dari molekul air di lingkungan sistem seperti terlihat pada Gambar 1.

Berdasarkan gambar tersebut ikatan peptide rentan terlepas oleh molekul air sehingga diberikan medan gaya (force field) yang diberikan agar ikatan asam amino tidak terganggu. Model yang digunakan yaitu OPLS-AA/L all-atom force field (2001 aminoacid dihedrals)yang di dalamnya terdapat interaksi gaya potensial Lennard-Jones yang bekerja pada tiap asam amino protein.

Gromacs menyediakan 3 bentuk yaitu cubic, triclinic, dan octahedron. Penelitian ini menggunakan bentuk kubik dengan jarak $1.5 \mathrm{~nm}$ di atas ikatan protein atau kubik dengan sisi 8,3 $\mathrm{nm}$. Muatan protein harus sama dengan muatan pada sistem yang berisi air. Muatan pada tiap atom protein lysozyme putih telur terlihat dalam aplikasi Gromacs memiliki muatan rata rata sebesar +8 coloumb sehingga agar setimbang harus dinetralkan denan menambah ion $\mathrm{Cl}^{-}$dalam $\mathrm{NaCl}$ sebesar 8 ion negatif agar sistem setimbang lalu dilakukan minimalisasi energi agar sistem tidak terpengaruh eneri dari luar dan berjalan secara terbatas.

Kesetimbangan dilakukan agar simulasi dapat berjalan dengan baik.
Kesetimbangan pada simulasi ini dilakukan dengan ensemble kanoikal (NVT) dan isothermal-isokhorik (NPT) yang divariasikan temperatur yaitu $300 \mathrm{~K}, 325 \mathrm{~K}$, dan $350 \mathrm{~K}$ berdasarkan persamaan (1) dan (2).

$$
\begin{aligned}
& K=\frac{3}{2} N k_{b} T \\
& P=\frac{2}{3} \frac{N}{V} K
\end{aligned}
$$

Dengan, $\mathrm{K}=$ energi kinetik $(\mathrm{J}), \mathrm{kb}=$ konstanta bolzman $\left(1,38 \times 10^{-23} \mathrm{~J} / \mathrm{K}\right), \mathrm{T}=$ temperatur $(\mathrm{K}), \mathrm{N}=$ jumlah molekul, $\mathrm{P}=$ tekanan $(\mathrm{Pa})$, dan $\mathrm{V}=$ volume $\left(\mathrm{nm}^{3}\right)$.

Simulasi dinamika molekul dilakukan dengan waktu 1 ns. Setelah dilakukan simulasi maka struktur protein akan berubah sehinga diperlukan analisis pada struktur protein lysozyme dengan menggunakan aplikasi Virtual Molecular Dynamics (VMD). Bentuk struktur yang ditampilkan menggunakan prinsip pendekatan dari algoritma Verlet agar mengetahui letak suatu atom dalam waktu dan keadaan tertentu. Persamaan algortitma Verlet dapat ditunjukan pada persamaan (3)

$R_{l}(t \pm \Delta t)=2 R_{l}^{\prime}(t)-R_{l}{ }^{\prime \prime}(t-\Delta t)+R_{l}{ }^{\prime \prime}(t) \Delta t^{2}+O \Delta t^{4}$

Dengan, $\mathrm{R}=$ posisi, $\mathrm{t}=$ waktu, $\Delta t=$ time step, dan $O=$ konstanta.

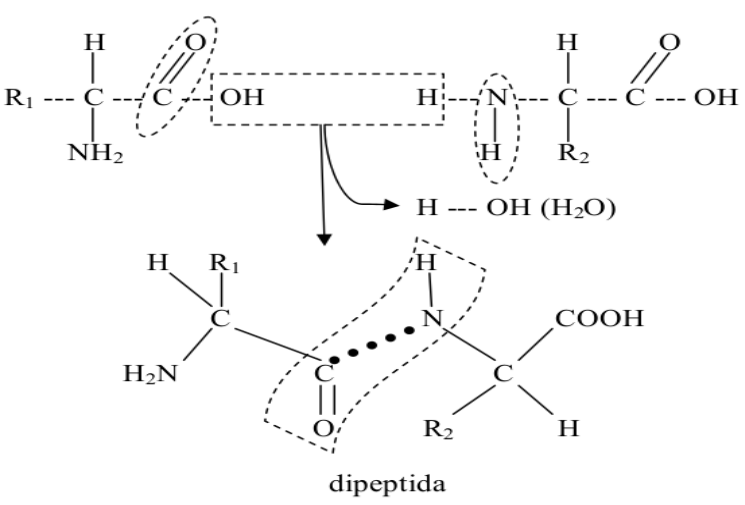

Gambar 1. Ikatan peptide protein 
Selanjutnya dilakukan analisis Root Mean Standart Deviation (RMSD) dan perhitungan energi potensial interaksi antar atom dalam ikatan asam amino protein lysozyme berdasarkan persamaan (4)

$U\left(R_{1 j}\right)=4 \varepsilon\left[\left(\frac{\sigma}{R_{1 j}}\right)^{12}-\left(\frac{\sigma}{R_{1 j}}\right)^{6}\right]$

Dengan, $\mathrm{U}=$ energi potensial, $\varepsilon=$ konstanta kekuatan interaksi $(\mathrm{J} / \mathrm{mol})$, $\sigma=$ panjang interaksi muatan, $\mathrm{R}=$ jarak [4] .

\section{HASIL DAN PEMBAHASAN}

\section{Prinsip Kerja Dinamika Molekul}

Simulasi dinamika molekul dapat dibagi tiga tahap yaitu inisialisasi, ekuibrasi, dan produksi [9]. Bentuk topologi sistem yang digunakan berbentuk kubik dengan panjan sisi sebesar 8,3 nm seperti ditunjukan pada Gambar 2. Bentuk toplogi sistem ini di dalamnya terdapat meolekul lysozyme putih telur yang diberikan ion $\mathrm{Cl}$ yang berwarna ungu yang di isi oleh air. Volume dari protein yaitu $123,376 \mathrm{~nm}^{3}$ dan volume keseluruhan yaitu $579,94 \mathrm{~nm}^{3}$

Saat dilakukan simulasi maka protein lysozyme yang berada di tengah - tengah box akan berjalan secara acak (random). Energi dalam ikatan protein dalam box harus diturunkan mencapai $1000 \mathrm{~kJ} / \mathrm{mol}$ agar pererakan protein lysozyme dapat bergerak sangat terbatas sehinga tidak terdapat gangguan dari luar.

\section{Pengaruh Variasi temperatur Saat Kesetimbangan}

Kesetimbangan menggunakan
ensemble kanoikal dan isothermalisokhorik yang berdasarkan persamaan (1) dan (2). Ensembel kanoikal yaitu ensamble dalam temperatur yang tetap serta jumlah molekul dan volume yang tidak berubah [4] atau biasa disebut kesetimbangan NVT. Pada penelitian ini sampel yang telah dibuat divariasikan temperatur berbeda yaitu pada temperatur $300 \mathrm{~K}, 325 \mathrm{~K}$, dan $350 \mathrm{~K}$ yang dilakukan dengan 50000 step dalam waktu 100 ps. Hasil kesetimbangan berupa grafik temperatur, densitas, dan tekanan dapat ditunjukan pada Gambar 3. Hasil tersebut menunjukan bahwa antar atom dalam ikatan tetap stabil meskipun dalam variasi temperatur $300 \mathrm{~K}, 325 \mathrm{~K}$, dan $350 \mathrm{~K}$. Lama waktu kesetimbangan, nilai akhir densitas, dan tekanan ditunjukan dalam Tabel 1.

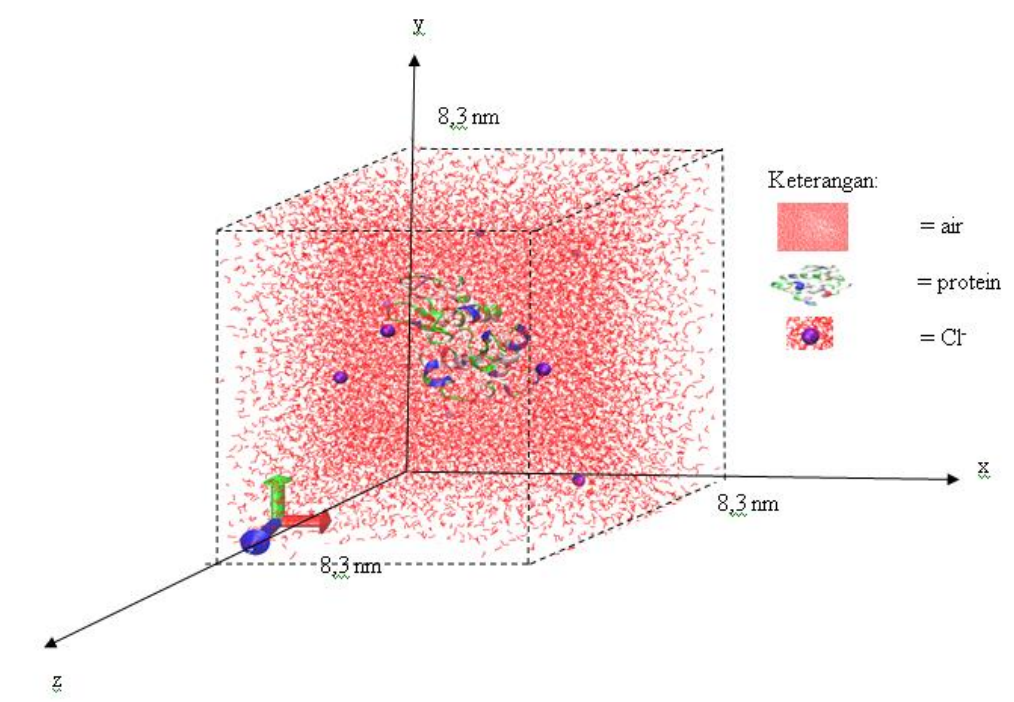

Gambar 2. Sistem protein lysozyme dalam box ukuran $8,3 \mathrm{~nm}$ 


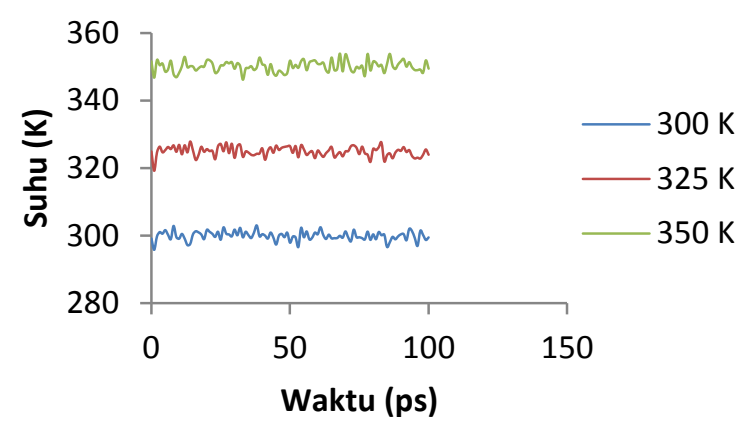

(a)

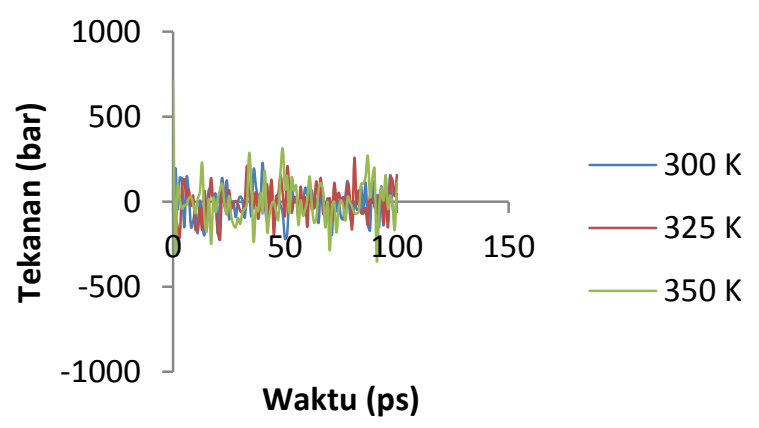

(b)

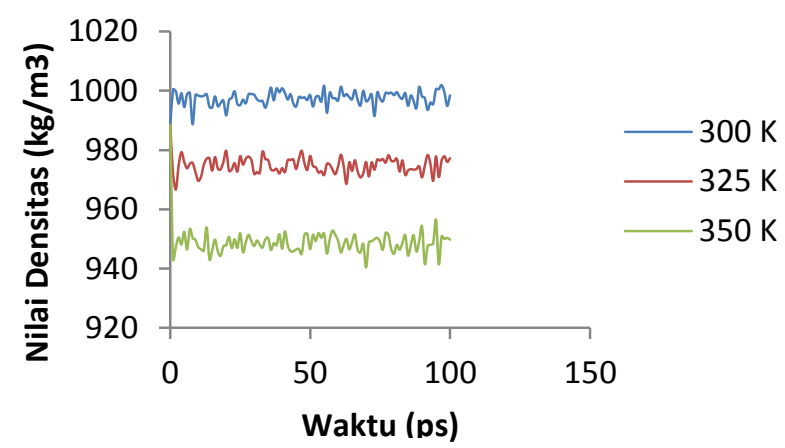

(c)

Gambar 3. Grafik Kesetimbangan (a) Temperatur, (b) Tekanan, dan (c) Densitas

Tabel 1 Kesetimbangan Dinamika Molekul

\begin{tabular}{|c|c|c|c|c|c|}
\hline \multirow{2}{*}{ No } & \multirow{2}{*}{$\begin{array}{l}\text { Temperatur } \\
\text { (K) }\end{array}$} & \multicolumn{2}{|c|}{ Waktu } & \multirow{2}{*}{$\begin{array}{l}\text { Tekanan } \\
\text { (bar) }\end{array}$} & \multirow{2}{*}{$\begin{array}{c}\text { Densitas } \\
(\mathrm{kg} / \mathrm{m} 3)\end{array}$} \\
\hline & & NVT & NPT & & \\
\hline 1 & 300 & $2 \mathrm{~h}: 54: 30$ & $3 \mathrm{~h}: 42: 52$ & 2,54 & 997,54 \\
\hline 2 & 325 & $3 \mathrm{~h}: 13: 07$ & $3 \mathrm{~h}: 44: 36$ & 4,84 & 974 \\
\hline 3 & 350 & $3 \mathrm{~h}: 22: 37$ & 4h:08:05 & 0,82 & 948,747 \\
\hline
\end{tabular}

Berdasarkan Tabel 4.3. menunjukan bahwa nilai temperatur mempengaruhi nilai tekanan dan densitas. Pada sampel temperatur $300 \mathrm{~K}, 325 \mathrm{~K}$ dan $350 \mathrm{~K}$ densitas akan semakin menurun yaitu berturut - turut $997,54 \mathrm{~kg} / \mathrm{m}^{3}, 974 \mathrm{~kg} / \mathrm{m}^{3}$, dan $948,747 \mathrm{~kg} / \mathrm{m}^{3}$ sedangkan nilai tekanan beruturut - turut 2,54 bar; 4,84 bar; dan 0,82 bar. Namun menurut[10] semakin besar nilai temperatur maka densitas akan semakin kecil dan nilai tekanan akan semakin besar dengan batasan temperatur lysozyme yaitu $345 \mathrm{~K}$ sehingga pada sampel dengan temperatur $350 \mathrm{~K}$ menunjukan protein lysozyme telah terdenaturasi yang ditandai dengan nilai tekanan semakin kecil yaitu 0,82 bar.
Simulasi dinamika molekul dilakukan untuk mengetahui energi yang terkandung dalam protein lysozyme saat terdenaturasi dan mengetahui nilai interaksi potensial gaya Lennard-Jones yang dilakukan berdasarkan pergerakan antara atom di protein dengan air dalam box. Simulasi dinamika molekul pada sampel $300 \mathrm{~K}$ dilakukan dengan memvariasikan waktu simulasi. Variasi waktu yang diberikan yaitu 0 ps, 200 ps, 400 ps, 600 ps, 800 ps, dan 1000 ps yang bertujuan untuk menentukan waktu yang tepat dalam simulasi. Hasil visualisasi dari simulasi dinamika molekul dalam variasi waktu dapat ditunjukan pada Gambar 4. 


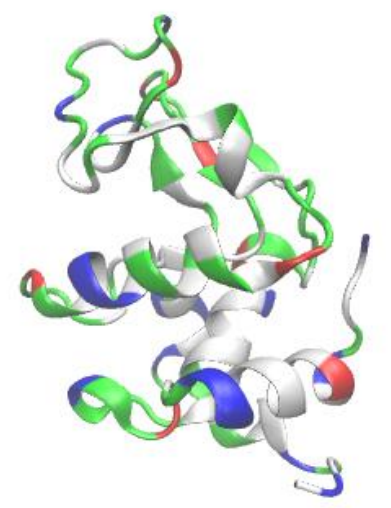

(a)

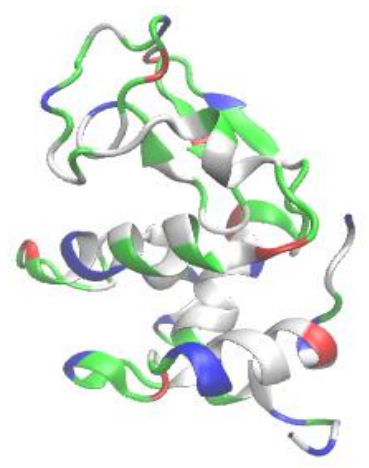

(d)

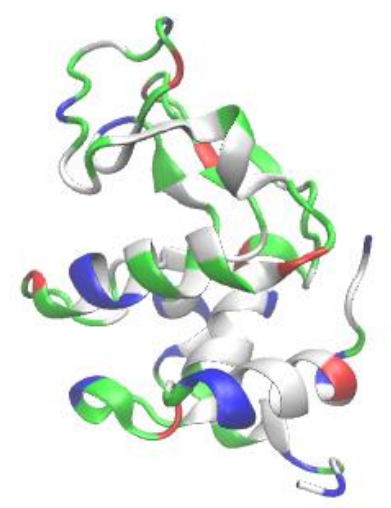

(b)

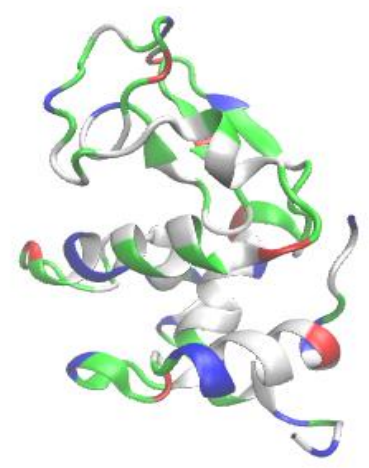

(e)

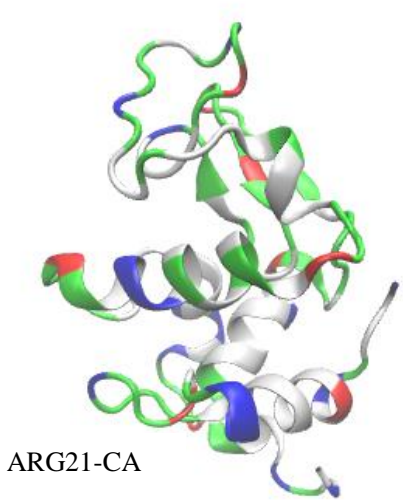

(c)

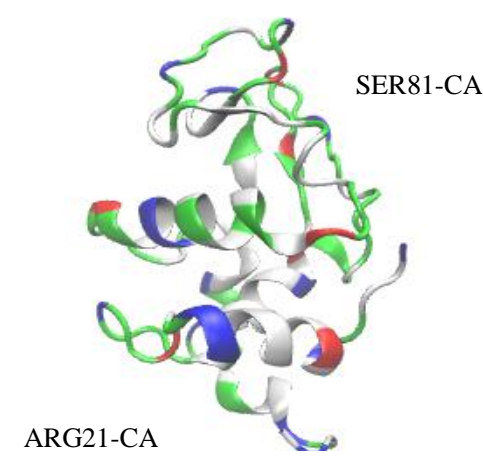

(f)

Gambar 4. Hasil simulasi dinamika molekul pada $300 \mathrm{~K}$ dalam waktu (a) 0 ps, (b) 200 ps, (c) 400 ps, (d) 600 ps, (e) 800 ps dan (f) 1000 ps.

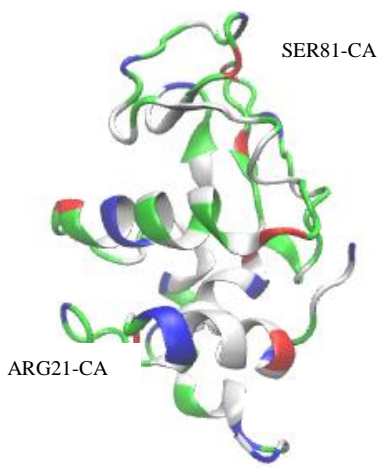

(a)

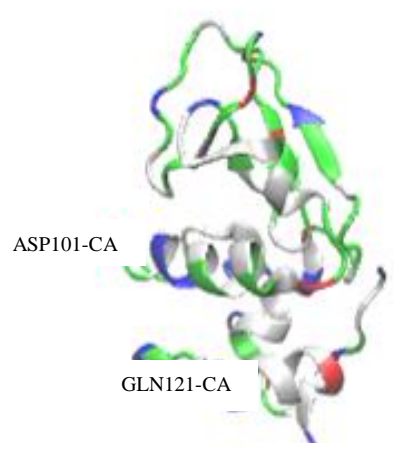

(b)

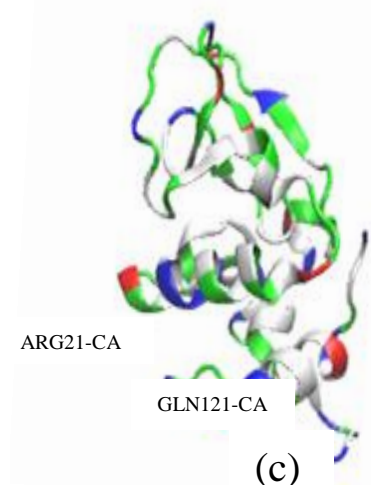

(c)

Gambar 5. Struktur protein lysozyme hasil simulasi dengan temperatur (a) $300 \mathrm{~K}$; (b) $325 \mathrm{~K}$; (c) $350 \mathrm{~K}$.

Pada penelitian ini protein tetap dapat dilakukan analisis dengan waktu 1 ns karena struktur protein masih tetap utuh walaupun terjadi unfolded state yang berada di satu titik. Pada sampel dengan temperatur $300 \mathrm{~K}$ membutuhkan waktu simulasi sebesar 1 hari 14 jam 24 menit, sampel $325 \mathrm{~K}$ membutuhkan waktu 1 hari 8 jam 41 menit 11 detik, sampel $350 \mathrm{~K}$ membutuhkan waktu 1 hari 6 jam 45 menit 36 detik. Hasil struktur protein setelah disimulasi ditunjukan pada Gambar 5. 
Stabilitas termal suatu protein merupakan kemampuan protein dalam mempertahankan struktur pada keadaaan folded sebagai respon terhadap energi tinggi. Unfolding terjadi saat keadaan protein tidak stabil sehingga memiliki energi yang lebih tinggi daripada keadaan folded [3]. Berdasarkan Gambar 5. terlihat bahwa terjadi perubahan lipatan struktur protein yang disebabkan oleh temperatur yang berbeda. Perubahan stuktur menjadi unfolded pada sampel $300 \mathrm{~K}$ terdapat 2 peristiwa unfolded yaitu pada rantai ARG21-CA dan SER81-CA mempunyai tekanan 2,54 bar, pada sampel $325 \mathrm{~K}$ terdapat 2 peristiwa unfolded yaitu pada rantai ASP101-CA dan GLN121-CA mempunyai tekanan 4,84 bar. Namun pada sampel ketiga yaitu sampel $350 \mathrm{~K}$ terdapat 1 peristiwa unfolded pada rantai ARG21CA dan menghilangnya rantai GLN121-CA dan tekanan menurun menjadi 0,82 bar akibat peristiwa masuknya air dalam protein sehingga membuat ikatan tersebut terganggu yang mengakibatkan protein terdenaturasi.

\section{Energi dalam Protein}

Pada saat unfolding energi yang berada dalam protein akan lebih tinggi daripada saat keadaan folding [3]. Peristiwa folding dan unfolding pada penelitian ini terjadi di rantai asam amino dalam satuan atomik sehingga dapat dihitung interaksi antar atom dengan menggunakan gaya van der walls. Perhitungan dalam interaksi gaya van der walls dapat dihitung menggunakan persamaan Lennard-Jones pada persamaan (4) sehingga hasil dalam bentuk grafik terlihat seperti Gambar 6.

Berdasarkan Gambar 6 terlihat bahwa nilai energi pada ketiga sampel cenderung stabil. Pada sampel 300 K, 325 K, dan 350 $\mathrm{K}$ besar energi rata rata dari interaksi van der walls dalam sampel berturut turut yaitu 2992,14 kJ/mol; 2994,55 kJ/mol; 2999,65 $\mathrm{kJ} / \mathrm{mol}$.

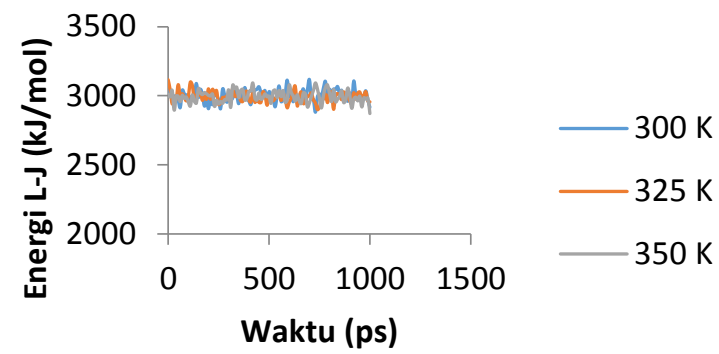

Gambar 6. Grafik nilai energi Lennard Jones dalam sampel

Besar nilai antar sampel dipengaruhi oleh jumlah atom yang memiliki kekuatan interaksi, jarak antar atom, serta besar muatan dalam atom pada sampel. Pengaruh temperatur dapat mempengaruhi struktur protein sehingga atom penyusunya menjadi berubah yang mengakibatkan jumlah ikatan yang berinteraksi dan jarak antar atom dapat berubah dan terjadi perubahan nilai energi pada tiap sampel.

\section{Analisis RMSD}

Hasil dari simulasi dinamika molekul perlu dilakukan analsis seperti analisis Root Mean Standart Deviasion (RMSD) yang bertujuan agar memperlihatkan protein dalam keadaan tetap stabil dan tidak terdenaturasi. Nilai RMSD sangat baik apabila tidak terjadi fluktuasi yang terlalu tajam hingga $0.1 \mathrm{~nm}$ [11]. Fluktuasi grafik RMSD yang terlalu tajam berarti adanya ikatan dari protein yang terlepas sejauh jarak tertentu sehingga protein dapat terdenaturasi. Analsis RMSD dapat ditunjukan dalam Gambar 7.

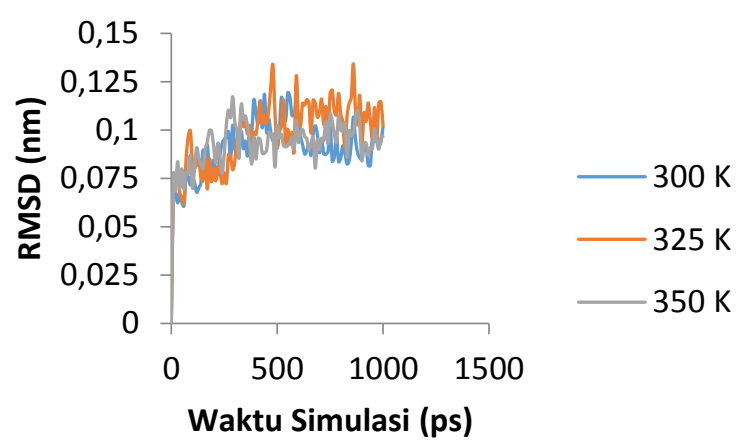

Gambar 7. Analsis Root Mean Standart Deviation (RMSD) 
Berdasarkan Gambar 7 terlihat bahwa tidak adanya grafik yang terjadi fluktuasi yang terlalu tajam. Pada sampel tersebut saat pada awal simulasi protein terganggu oleh adanya perubahan unfolded pada semua sampel. Namun terdapat puncak lainya pada waktu 421 ps dan pada 843 ps yang ditandai dengan adanya perubahan unfolded state pada sampel $325 \mathrm{~K}$ yang lebih banyak yang mengindikasi bahwa interaksi ikatan asam amino mulai terganggu. Pada sampel $350 \mathrm{~K}$ pada waktu 1 ps terjadi kenaikan RMSD yang tajam dari $0 \mathrm{~nm}$ ke $0,07 \mathrm{~nm}$ yang mengindikasi bahwa protein telah terdenaturasi karena protein lysozyme hanya mampu bertahan pada temperatur $345 \mathrm{~K}$ [10].

\section{KESIMPULAN}

Simulasi dinamika molekul berjalan dengan fungsi waktu yang dapat ditunjukan bahwa semakin besar temperatur maka waktu yang dibutuhkan untuk simulasi dinamika molekul akan semakin cepat yaitu pada temperatur $300 \mathrm{~K}, 325 \mathrm{~K}, 350 \mathrm{~K}$ berturut - turut yaitu 1 hari 14 jam 24 menit, 1 hari 8 jam 41 menit 11 detik, 1 hari 6 jam 45 menit 36 detik.Struktur protein lysozyme dapat terganggu akibat perubahan temperatur yaitu ketika temperatur $300 \mathrm{~K}$ terjadi unfolding state di dua titik yaitu rantai ARG21-CA dan SER81-CA mempunyai tekanan 2,54 bar, temperatur $325 \mathrm{~K}$ terjadi unfolding state di dua titik yaitu rantai ASP101-CA dan GLN121-CA mempunyai tekanan 4,54 bar, dan temperatur $350 \mathrm{~K}$ terjadi unfolding state di satu titik lalu terjadi folding state kembali di dua titik yaitu rantai ARG21-CA dan menghilangnya rantai GLN121-CA serta nilai tekanan menurun menjadi 0,82 bar yang mengindikasi protein telah terdenaturasi. Nilai energi potensial Lennard-Jones pada temperatur $300 \mathrm{~K}, 325$ $\mathrm{K}$, dan $350 \mathrm{~K}$ berturut turut yaitu 2992,14 $\mathrm{kJ} / \mathrm{mol} ; \quad 2994,55 \quad \mathrm{~kJ} / \mathrm{mol} ; \quad 2999,65$
$\mathrm{kJ} /$ mol.Berdasarkan data analisis RMSD, protein pada temperatur $325 \mathrm{~K}$ mulai terganggu pada waktu 421 ps dan 843 ps sebesar $0,1 \mathrm{~nm}$ ke $0,13 \mathrm{~nm}$ lalu pada temperatur $350 \mathrm{~K}$ protein terdenaturasi saat waktu 1 ps yang ditandai kenaikan yang sangat drastis dari $0 \mathrm{~nm}$ ke $0.07 \mathrm{~nm}$.

\section{DAFTAR PUSTAKA}

[1] A. D. Astuti and A. B. Mutiara, "Simulasi dinamika molekuler protein dengan aplikasi gromacs," Teh. Inform. dan Ind., vol. 1, no. 2, pp. 1-9, 2011.

[2] S. W. J. and C. O. Z., Egg Science and Technology Food Product. United State: Howorth Press Inc, 1994.

[3] J. Hati, "Analisis Kestabilan Protein 1Gb1 Menggunakan Simulasi Dinamika Molekul,” Bogor: Institut Pertanian Bogor, 2014.

[4] A. Witoelar, Perancangan dan Analisis Simulasi Dinamika Molekul Ensamble Mikrokanoikal dan Kanoikal dengan Potensial LennardJones. Bandung: Departement Teknik Fisika ITB, 2002.

[5] H. K. Dipojono, "Simulasi Dinamika Molekul (Sebuah Pengantar )," in Hamburan Neutron dan Sinar X ke4, 2001, pp. 1-4.

[6] F. Fathurrahman and S. Haryono, "Simulasi Dinamika Molekular Proses Adhesi pada Model Nanopartikel 2D," in Seminar Kontribusi Fisika, 2011, pp. 5-6.

[7] R. Protein Data Bank, About PDB Archieve and RSCB PDB. 2018. 
[8] A. Poedjadi, Dasar - Dasar Biokimia. Jakarta: Universitas Indonesia, 1994.

[9] P. Pandiangan, A. Arkundato, and I. Komalasari, Model Pembelajaran Kimia Fisika Berbasis Simulasi Dinamika Molekul. Batam: Universitas Terbuka, 2011.

[10] A. De Francesco, M. Marconi, S. Cinelli, G. Onori, and A. Paciaroni,
"Picosecond Internal Dynamics of Lysozyme As Affected by Thermal Unfolding in Nonaqueous Environment," Biophys. J., vol. 86, no. 1 I, pp. 480-487, 2004.

[11] Ma. Abraham et al., GROMACS Reference Manual 2016.3. Netherland: University of Groningen, 2016. 
Harry dkk.: Analisis Dinamika Molekul Protein Lysozyme Putih Telur Dengan Model Potensial LennardJones Menggunakan Aplikasi Gromacs 